Izumi, Volume 5, No 2, 2016

e-ISSN: 2502-3535, p-ISSN: 2338-249X

Tersedia online di http://ejournal.undip.ac.id/index.php/izumi

\title{
KOTOWAZA DALAM KAJIAN LINGUISTIK KOGNITIF: PENERAPAN GAYA BAHASA SINEKDOK
}

\author{
Adisthi Martha Yohani \\ Universitas Widyatama \\ Email: adisthi.martha@widyatama.ac.id
}

\begin{abstract}
[Kotowaza in Cognitive Linguistic Analysis: The Use of Synecdoche]. This paper analyzes kotowaza using synecdoc through the study of cognitive linguistic. The background of this research is the difficulty of understanding relationships between the meanings of the kotowaza on foreign learners because of cultural differences and lack of dictionaries that support the process of understanding kotowaza deeply.

The purpose of this research is to understand kotowaza deeply, determine the connection of these lexical-figurative meaning of Japanese proverbs using synecdoche based on the study of cognitive linguistics. The method used is a qualitative method in approach of cognitive linguistics. At the end of the study, it is concluded that synecdochecan be used to analyze the correlation between the lexical meaning and figurative meaning of kotowaza that contains a word or two which represents wider or smaller meaning such as kotowaza which related to the characteristics of an area or kotowaza that associated with number.
\end{abstract}

Keywords: kotowaza, Japanese proverb, cognitive linguistic, synecdoche

\section{PENDAHULUAN}

Dalam kehidupan bermasyarakat, manusia dituntut menjaga hubungan sesama manusia dengan bertutur santun agar tidak melukai perasaan mitra tutur. Pada situasi seperti ini,peribahasa yang dalam bahasa Jepang disebut dengan kotowaza memainkan peran penting dalam komunikasi karena mengandung ungkapan halus dan ajaran moral. Selain itu, dalam bentuk yang singkat kotowazadapat mengungkapkan maksud pembicara tanpa harus berujar panjang lebar.

Menurut Koujien (1991: 953), definisi kotowazaadalah:

古くから人に言い習わされた言葉、 教訓、風刺などに意を寓した短句や秀句。

Furuku kara hito ni iinarawasareta kotoba, kyoukun, fuushi nado no $i$ wo guushita tanku ya shuuku.

'Merupakan kata-kata yang diucapkan orang sejak lama, maksud hati seperti pengajaran, sindiran dan sebagainya dinyatakan secara tidak langsung dengan menggunakan kombinasi kata-kata pendek namun indah.'

Untuk memahami kotowaza biasanya dikaji berdasarkan kaitan antarmaknanya, yaitu dengan menjelaskan hubungan antara makna leksikal dan makna kiasan tersebut. Akan tetapi, penjelasan yang terdapat dalam kamus kotowaza biasanya hanya memuat makna leksikal dan kiasannya saja tanpa penjelasan lebih rinci sehingga hubungan antara makna leksikal dan makna kiasannya sulit dipahami. Pada akhirnya, cara yang dilakukan adalah menghafal bunyi dan makna kotowaza tersebut. Akan tetapi, menghafal kotowaza bulat-bulat menimbulkan kesulitan tersendiri, apalagi jika saat mengafalnya ternyata terdapat kotowaza yang makna leksikal dan makna kiasannya tidak berterima dengan logika dikarenakan perbedaan budaya. Dengan kata 
Izumi, Volume 5, No 2, 2016

e-ISSN: 2502-3535, p-ISSN: 2338-249X

Tersedia online di http://ejournal.undip.ac.id/index.php/izumi

lain, untuk memahami kotowaza tidak cukup hanya dengan menghafal bunyi dan maknanya saja, tetapi juga dibutuhkan pengetahuan tentang latar belakang sosial dan budaya pembentuk kotowaza di mana kotowaza itu berkembang. Bagi pembelajar bahasa Jepang yang berbeda latar belakang sosial dan budayanya maka akan menjadi kendala dalam memahami kotowaza ini secara mendalam.

濡れ手で粟

Nure te de awa

'Sekoi dengan tangan basah'

Makna peribahasa ini adalah 'mendapatkan keuntungan tanpa bersusah payah'. Peribahasa ini merupakan peribahasa berbentuk pengandaian yang diadaptasi dari kehidupan sehari-hari masyarakat terutama petani. Awa (粟) adalah bulir padi yang kecil dan ringan yang biasanya dimakan oleh burung-burung kecil, dalam bahasa Indonesia disebut dengan sekoi. Jika digenggam dengan tangan basah, sekoi akan melekat dalam jumlah banyak di tangan. Berdasarkan fakta inilah arti dari peribahasa tersebut diumpamakan.

Kaneko(1982:123) mengungkapkan bahwa jika peribahasa ini digunakan untuk mengomentari perihal orang lain, ada sedikit kecemburuan yang tersirat, semetara jika mendeskripsikan diri sendiripun kita akan mudah merasa rendah diri karena berpikir bahwa orang lainpun memiliki kecemburuan yang sama. Pada kutipan kalimat tersebut tercermin pandangan masyarakat Jepang pada umumnya yang menganggap bahwa sesuatu yang didapatkan bukan dari kerja keras akan sulit diterima oleh orang lain bahkan oleh diri sendiri.

Berikut adalah penggalan percakapan yang penulis peroleh dari serial drama Hana Yori Dango Iperihal misinterpretasi makna kotowaza.

$$
\begin{array}{ll}
\text { お母さん } & : \text { じゃ、つぎ、「濡れ手で } \\
& \text { 粟」。 } \\
\text { Okaasan } & : J a, \text { tsugi, nure te de awa. } \\
\text { Ibu } & : \text { Ya, selanjutnya, “nure te de } \\
& \text { awa”. }
\end{array}
$$

お父さん:それつぎの期末試験にきつ と出るぞ。

Otousan :Sore tsugi no kimatsu shiken ni kitto deru zo.

Ayah :Itu pasti akan keluar di ujian akhir selanjutnya.

すすむ :わかった。洗いものをして たら手が泡だらけなちゃっ て,かゆいよって意味。

Susumu :Wakatta. Araimono wo shitetara te ga awadarake nachatte, kayui yo tte imi.

Susumu :Aku mengerti. Artinya, ketika sedang mencuci, tangan akan penuh dengan busa gelembung, gatal tho.

お父さん：はい、そんな時にはごむ手 袋! 濡れ手で泡でも大丈夫。

Otousan :Hai, sonna toki ni wa gomutebukuro! Nure te de awa demo daijoubu.

Ayah :Ya, pada saat seperti itu, gunakan sarung tangan karet. Meskipun tangan penuh dengan gelembung busa, tidak apa-apa.

お母さん：ぶうぶう!

Okaasan : Buubuu!

Ibu : Salah!

すすむ :じゃ、正解は？

Susumu :Ja, seikai wa?

Susumu :Kalau begitu apa jawaban yang benar?

お母さん:大した努力もせずに、易々

と大きいな利益を得ること、 濡れ手で粟といいます。

Okaasan : Taishita doryoku mo sezuni, yasuyasu to ookii na rieki wo eru koto, nure te de awa to iimasu.

Ibu : Mendapatkan keuntungan dengan mudahnya tanpa melakukan usaha yang berarti disebut dengan nure te de awa.

(Drama: Hana Yori Dango) 
Izumi, Volume 5, No 2, 2016

e-ISSN: 2502-3535, p-ISSN: 2338-249X

Tersedia online di http://ejournal.undip.ac.id/index.php/izumi

Dalam dialog di atas tokoh Susumu yang sedang berlatih tanya jawab soal ujian akhir semester dengan ibunya menjawab pertanyaan dengan jawaban yang salah. Susumu salah mengartikan kata "awa" (粟) yang artinya sekoi menjadi “ $a w a$ " (泡) yang berarti gelembung busa.

Dari percakapan di atas dapat dipahami bahwa untuk memahami sebuah peribahasa, makna tiap katanya harus dipahami terlebih dahulu untuk membantu memahami makna yang sebenarnya dalam peribahasa tersebut. Namun tidak cukup dengan mengerti makna harafiahnya saja, untuk memahami makna sebuah ungkapan seperti peribahasa maka diperlukan pemahaman tentang latar belakang sosial dan budaya masyarakat dimana peribahasa itu berkembang.

Penelitian yang berhubungan dengan kotowaza dapat dikaji melalui linguistik kognitif. Linguistik kognitif memandang bahwa, makna suatu kata terutama dalam polisemi tidak muncul begitu saja. Melainkan ada yang memotivasi dan melatarbelakanginya. Untuk mendeskripsikan hubungan antarmakna dalam polisemi, bisa melalui gaya bahasa. Momiyama (1997 \& 1998) dalam Sutedi (2008: 192) menggunakan gaya bahasa sinekdok dalam mendeskripsikan hubungan makna polisemi. Menurut Keraf, (2010:142) sinekdok adalah semacam bahasa figuratif yang mempergunakan sebagian dari sesuatu hal untuk menyatakan keseluruhan (pars pro toto) atau mempergunakan keseluruhan untuk menyatakan sebagian (totum pro parte).Serupa dengan polisemi yang makna dasar dan makna perluasannya dapat dijelaskan melalui majas, pendeskripsian makna kiasan dalam peribahasa pun dapat dilakukan dengan menggunakan majas tersebut.

Tulisan ini akan memaparkan ihwal kotowaza dalam bahasa Jepang, mengkaji tentang hubungan budaya dan kotowaza dalam masyarakat Jepang dan menganalisis hubungan antarmakna dalam kotowaza mengunakan majas sinekdok berdasarkan kajian linguistik kognitif.

\section{LANDASAN TEORI}

Penelitian yang dilakukan Arimi (2005) menyebutkan bahwa peribahasa masih populer di kalangan masyarakat Jepang dan Indonesia. Berdasarkan penelitian Arimi, hanya 6 orang dari 87 orang responden Jepang $(6,9 \%)$ yang mengatakan bahwa mereka jarang menggunakan kotowaza atau sama sekali tidak menggunakannya tapi mengetahui makna kotowaza tersebut sementara sisanya, yaitu 81 orang $(93,1 \%)$ responden menggunakannya. Sementara itu, tidak seorang pun dari responden Indonesia yang berjumlah total 65 orang yang tidak menggunakan peribahasa dalam kehidupan mereka. Dari data tersebut dapat dipahami bahwa peribahasamasih digunakan oleh banyak orang baik di Jepang maupun Indonesia, oleh karena itu, layak kiranya dilakukan penelitian mengenai kotowaza tersebut.

Penelitian yang dilaksanakan Yuliannie (2006) membahas mengenai perbandingan kotowaza Jepang dan Indonesia yang berhubungan dengan 'mata manusia'. Dari 28 buah kotowaza Jepang yang diteliti, seluruhnya memiliki padanan makna yang sama dalam kotowaza Indonesia, dimana lima diantaranya merupakan kotowaza Jepang yang memiliki padanan dengan kotowaza Indonesia yang juga berhubungan dengan mata. Akan tetapi, penelitian ini tidak membahas budaya secara rinci dan tidak menyertakan contoh penggunaan kotowaza tersebut dalam kalimat.

\subsection{Linguistik Kognitif dan Penerapannya dalam Penelitian Bahasa}

Linguistik kognitif muncul pada tahun 1980-an. Tokoh aliran ini adalahGeorge Lakkof, Mark Johnson, Ronald W Langacker dan yang lainnya.Perluasan makna pada suatu kata yang berpolisemi tidak terjadi begitu saja, melainkan para pemakai bahasa memiliki alasan (motivasi) mengapa suatu kata yang memiliki makna tertentu digunakan pula untuk menyatakan makna yang lainnya, sehingga menjadi suatu 
Izumi, Volume 5, No 2, 2016

e-ISSN: 2502-3535, p-ISSN: 2338-249X

Tersedia online di http://ejournal.undip.ac.id/index.php/izumi

kesepakatan bersama. Perubahan, pergeseran, dan perluasan makna kata tersebut terjadi akibat adanya berbagai perkembangan dan kemajuan yang dialami manusia pemakai bahasa itu sendiri yang tentunya dapat dideskripsikan dari sudut pandang tertentu.

Linguistik kognitif memandang pengetahuan linguistik sebagai bagian dari kognisi umum dan pemikiran; perilaku linguistik tidak terpisah dari kemampuan kognitif umum lainnya yang memperbolehkan proses mental berpikir logis, ingatan, perhatian dari pembelajaran, akan tetapi dipahami sebagai satu kesatuan bagian daripadanya.

Yoshimura (1995) dalam Sutedi (2008: 171) menegaskan bahwa maksud kognitif yang digunakan dalam aliran ini yaitu seluruh kegiatan pikiran manusia dalam memahami dan memaknai setiap pengalaman barunya secara subjektif dalam mengatur berbagai informasi yang diperoleh dengan tepat. Sumbangan linguistik kognitif dalam penelitian kosakata sangat besar terutama dalam mendeskripsikan makna kata dalam semantik kognitifnya.

\subsection{Sinekdok}

Sutedi (2008: 197) mengungkapkan bahwa bentuk hubungan dalam gaya bahasa sinekdok, hanya satu macam, yaitu sesuatu yang digunakan untuk menyatakan sesuatu yang lebih khusus, atau sebaliknya.

\section{煮え湯を飲ませる}

Nieyu wo nomaseru

Idiom yang secara leksikal bermakna

diberi minum air mendidih ini digunakan untuk menyatakan arti mendapat bahaya. Momiyama dalam Sutedi (2009:103) menjelaskan bahwa minum air panas merupakan salah satu jenis dari bahaya, jadi bahaya secara umum dinyatakan dengan minum air panas yang merupakan salah satu jenis dari bahaya, sehingga termasuk ke dalam sinekdok.

Sinekdok adalah suatu istilah yang diturunkan dari kata Yunani synekdechesthai yang berarti menerima bersama-sama. Sinekdok adalah semacam bahasa figuratif yang mempergunakan sebagian dari sesuatu hal untuk menyatakan keseluruhan (pars pro toto) atau mempergunakan keseluruhan untuk menyatakan sebagian (totum pro parte). Misalnya:

Setiap kepala dikenakan sumbangan sebesar Rp. 1000,-

Dalam pertandingan sepak bola antara Indonesia melawan Malaysia di Stadion Utama Senayan, tuan rumah menderita kekalahan 3-4(Keraf, 2010:142).

\section{METODE PENELITIAN}

Penelitian yang akan penulis lakukan adalah penelitian kualitatif yang mendeskripsikan hubungan antarmakna pada kotowaza menggunakan majas sinekdok berdasarkan kajian linguistik kognitif.

\subsection{Teknik Pengolahan Data}

Dalam penelitian ini penulis melakukan tiga tahap yaitu sebagai berikut:

1. Tahap Persiapan

Dalam tahap ini penulis melakukan pengumpulan data terlebih dahulu dari buku, video, internet yang dianggap relevan. Pengumpulan datamenggunakan kartu data guna mendaftar kotowaza. Dengan demikian data berupa contoh konkrit dalam suatu konteks (jitsurei).Teknik yang digunakan adalah teknik catat pada buku ajar dan teknik simak catat pada data yang diambil dari video drama/film. Dalam proses pengumpulan data, peneliti bertindak langsung sebagai instrumen penelitian.

\section{Tahap Pelaksanaan}

Data kotowaza yang sudah diperoleh akan dikaji makna leksikalnya terlebih dahulu. Setelah diketahui arti tiap katanya, maka akan dikaji makna kiasannya dengan merujuk pada kamus kotowaza. Kemudian, makna leksikal dan kiasan kotowaza tersebut akan dihubungkan melalui kajian linguistik kognitif dengan menggunakan majas sinekdok. Teknik yang digunakan dalam menganalisis data adalah teknik parafrase (ubah ujud).

\section{Pelaporan}


Izumi, Volume 5, No 2, 2016

e-ISSN: 2502-3535, p-ISSN: 2338-249X

Tersedia online di http://ejournal.undip.ac.id/index.php/izumi

\section{PEMBAHASAN}

Sinekdok adalah semacam bahasa figuratif yang mempergunakan sebagian dari sesuatu hal untuk menyatakan keseluruhan (pars pro toto) atau mempergunakan keseluruhan untuk menyatakan sebagian (totum pro parte). Di bawah ini merupakan kotowaza yang kaitan antarmaknanya dapat dianalisis menggunakan majas sinekdok:

\section{1)所変われば品変わる}

\section{Tokoro kawareba shina kawaru}

'Jika tempat berubah, barang berubah'

Berbeda tempat maka akan berbeda pula kebiasaannya

Lahirnya sebuah peribahasa biasanya dipengaruhi oleh budaya daerah setempat. Salah satu faktor yang menyebabkan munculnya peribahasa ini adalah perbedaan kondisi geografis. Jepang yang kondisi geografisnya berbentuk negara kepulauan yang membentang dari utara ke selatan menyebabkan iklim di wilayah utara dan selatan jauh berbeda.

Tidak hanya wilayah utara dan selatan saja, wilayah barat dan timurnya pun memiliki perbedaan iklim dikarenakan keberadaan laut Jepang yang mengelilingi pantai barat dan samudra Pasifik yang mengelilingi pantai timur Jepang. Pulau Okinawa yang terletak di ujung selatan kepulauan Jepang berhawa cukup panas, sementara pulau Hokkaido yang berada paling utara merupakan tempat beriklim subtropis dengan hawa yang sangat dingin, bahkan pada musim panas suhunya tidak sepanas di pulau lain.

Adanya perbedaan iklim semacam ini memberi pengaruh terhadap banyaknya perbedaan tiap wilayah di Jepang. Baik dari segi pakaian, tata krama, bahasa dan sebagainya. Bahkan barang yang sama pun ada kalanya akan beda memiliki nama yang berbeda. Perbedaan lainnya dapat kita lihat dari bidang kuliner. Karena Jepang adalah negara kepulauan, maka selera masyarakatnya pun berbeda sesuai daerah masing-masing. Sebagai contoh, perihal kaldu sup, orang Kanto menyukai yang asin sementara orang Kansai lebih menyukai kaldu yang rasanya hambar.

Manusia yang terbiasa dengan hal-hal yang ada di daerah tempat tempat ia hidup, akan menjumpai hal yang mengejutkan jika pergi ke daerah lain. Melihat hal yang belum pernah dilihat, mendengar kata-kata yang belum pernah didengar, makanan maupun tata krama akan berbeda dari hal yang biasa dilakukan di daerah masing-masing. Sebagai hasilnya, karena bertumpuknya pengalaman yang seperti inilah muncul peribahasa「所変 れば品変る」。

Dalam peribahasa ini tersirat perasaan kagum. Pada jaman dahulu, karena sulitnya sistem transportasi, kesempatan untuk pergi ke daerah lain pun sedikit sehingga pengetahuan tentang daerah lain menjadi terbatas, dan semakin terbatasnya kesempatan untuk pergi ke daerah luar maka perasaan kagum pun akan semakin kuat. Para leluhur orang Jepang mengungkapkan pengalamannya ke dalam peribahasa ini setelah mengalami perjalanan ke luar daerah dimana kemudian mereka menemukan fakta bahwa terdapat perbedaan antara daerah tempat tinggalnya dengan daerah baru yang dikunjunginya. Peribahasa ini mengajarkan pada manusia bahwa suatu daerah memiliki memiliki karakteristik yang berbeda dengan daerah lainnya. Peribahasa yang berhubungan dengan karakteristik daerah ini merupakan salah satu contoh keikenteki kotowaza.

Untuk menjelaskan kaitan antara makna leksikal dan makna kiasan dari peribahasa ini dapat digunakan majas sinekdok. Kanji 「品」 (shina) yang memiliki makna dasar 'benda/barang' merujuk pada 'benda secara luas', tidak hanya benda/barang yang berwujud fisik saja. Benda secara luas ini dapat berupa makanan dan produk pertanian lokal yang berwujud fisik maupun yang tidak seperti bahasa, adat istiadat dan kebiasaan. Jadi, kanji「品」 yang sifatnya khusus digunakan untuk menunjukkan hal yang lebih umum/luas lagi maknanya. Dengan kata lain, 
peribahasa ini mengandung majas sinekdok khusus-umum.

Penggunaan peribahasa ini dapat dilihat dalam data kalimat berikut:

$$
\text { 「所変われば品変わる」という彥 }
$$

があります。土地が違えば、それぞれの 土地に他の所と異なった産物があり、風 俗や習慣なども違うという意味です。

日本は面積が約 37 万平方キロメ ートルで、あまり広い国ではありません が、各地の様子には大きな違いがありま す。日本の各地を旅行すると、この諺の とおりであることがよく分かります。

'Tokoro kawareba shina kawaru' to iu kotowaza ga arimasu. Tochi ga chigaeba, sorezore no tochi ni hoka no tokoro to kotonatta sanbutsu ga ari, fuuzoku ya shuukan nado mo chigau to iи imi desu.

Nihon wa menseki ga yaku 37 man heihou kiromeetoru de, amari hiroi kuni dewa arimasen ga, kakuchi no yousu ni wa ooki na chigai ga arimasu. Nihon no kakuchi o ryokou suru to, kono kotowaza no toori de aru koto ga yoku wakarimasu.

'Ada peribahasa yang berbunyi 「所 変われば品変わる」. Artinya adalah jika berbeda daerah, maka di masing-masing daerah ada barang yang berbeda dengan di tempat lain, tradisi, kebiasaan dan yang lainnya juga berbeda.

Luas wilayah Jepang kira-kira 370 kilometer persegi, meskipun bukan Negara yang luas, ada perbedaan yang besar pada keadaan tiap wilayah. Jika bepergian ke tiap daerah di Jepang, kebenaran peribahasa ini akan sangat dimengerti.'

(Kawase,1996:10)

\footnotetext{
Dari pemakaian peribahasa dalam kalimat diatas dapat kita pahami bahwasannya meskipun Jepang adalah negara yang wilayahnya tidak luas, namun masing-masing daerah akan berbeda satu sama lain baik dari segi materil maupun tidak. Masyarakat Jepang adalah orang yang menghargai perbedaan, mengagumi dan mau mempelajari perbedaan tersebut. Sikap semacam ini terbentuk dari banyaknya perbedaan itu sendiri di Jepang.
}

2)十人十色

\section{Juunintoiro}

'Sepuluh orang sepuluh warna'

Setiap orang memiliki pemikiran masingmasing

Salah satu ciri keikenteki kotowaza berdasarkan Sekai Daihyakka Jiten adalah peribahasa yang berhubungan dengan perilaku manusia sehari-hari. Peribahasa merupakan pengalaman panjang nenek moyang yang terkristalisasi. Pada masa lalu, dalam hidup berkelompok akan ada orang yang dianggap sebagai sesepuh kampung untuk membimbing dan memberi nasehat. Dari pengalaman panjang mereka dalam mengamati perilaku manusia sehari-hari maka lahirlah kalimat bijak yang singkat berupa keikenteki kotowaza dimana salah satu contohnya adalah peribahasa ini.

Bentuk asal dari peribahasa ini adalah 「人人寄れば十色」。「色」 yang dimaksudkan pada peribahasa ini adalah 「W ろいろ」 yang artinya adalah "bermacammacam”. Maksud dari peribahasa「十人寄れ ば十色」 ini adalah jika ada sepuluh orang, maka masing-masing dari sepuluh orang tersebut akan berbeda satu sama lain. Akan tetapi, "berbeda" yang dimaksud pada peribahasa ini bukanlah perbedaan yang berhubungan dengan bentuk fisik, meskipun tentunya perihal fisik pun sudah tentu akan berbeda satu sama lain, akan tetapi yang dimaksudkan dalam peribahasa ini adalah perbedaan yang berhubungan dengan mentalitas seperti pemikiran, sifat, hobi, selera dan hal lainnya.

Di dunia ini tidak akan ada manusia yang sama persis mentalitasnya. Meskipun memiliki hobi yang sama, belum tentu perihal selera akan serupa dan meskipun memiliki pendapat yang sama dalam satu hal, belum tentu perihal lain akan sependapat pula. Peribahasa ini mengajarkan pada manusia bahwa masing-masing manusia memiliki karakter dan pemikirannya sendiri. Oleh karena itu, setiap orang harus menghormati pendapat orang lain, seseorang tidak dapat memaksakan pendapat pribadi 
Izumi, Volume 5, No 2, 2016

e-ISSN: 2502-3535, p-ISSN: 2338-249X

Tersedia online di http://ejournal.undip.ac.id/index.php/izumi

kepada orang lain karena orang lain mempunyai pemikirannya sendiri.

Hubungan antarmakna pada peribahasa ini dapat dijelaskan dengan majas sinekdok khusus-umum. Kanji 「十」 pada frasa「十人」 merujuk pada jumlah orang. Jika ada sepuluh orang, maka sepuluh macam pula pemikirannya. Bukan berarti jumlah manusia sebenarnya hanya sepuluh orang, tetapi angka sepuluh ini hanya merupakan angka yang merepresentasikan banyaknya jumlah manusia. Demikian pula dengan kanji

「十」 pada kata「十色」, jumlah 「色」 dari masing-masing manusia itu sangat banyak, angka sepuluh tersebut hanya merupakan angka yang merepresentasikan banyaknya jumlah macam/jenis dari tiap-tiap orang. Dengan demikian, angka sepuluh pada peribahasa ini merupakan angka yang merepresentasikan jumlah yang sangat banyak, baik itu jumlah manusia maupun jumlah jenis manusia itu sendiri. Penggunaan angka sepuluh yang lebih khusus untuk menunjukkan 'jumlah yang sangat banyak' yang merupakan hal yang lebih umum ini merupakan bentuk penggunaan majas sinekdok khusus-umum.

Berikut contoh penggunaan peribahasa ini di dalam kalimat:

$$
\text { 食べものの好みは十人十色で、社 }
$$
員食堂のメニューには苦情が絶えない。

Tabemono no konomi wa juunintoiro de, shain shokudou no menyuи ni wa kujou ga taenai.

Karena makanan kesukaan "juuninntoiro", keluhan pada menu kantin karyawan tidak pernah berakhir.

（四字熟語辞典 software）

Pada contoh kalimat di atas, dapat kita pahami bahwa pada tempat umum seperti kantin karyawan, perihal perbedaan selera menjadi masalah utama. Di kantin karyawan, kita tidak dapat memilih menu yang akan dimakan karena biasanya menu makanan setiap harinya sudah ditentukan oleh pihak pengelola kantin sementara makanan kesukaan masing-masing orang berbeda. Padahal menu makanan yang disediakan terbatas pilihannya. Begitu pula dengan selera, ada yang menyukai cita rasa makanan yang dihidangkan, ada pula yang merasa cita rasa makanan tersebut tidak cocok dengan seleranya. Ada yang menyukai makanan pedas tetapi tidak menyukai rasa asin maupun sebaliknya, ada yang menyukai manis, pahit, asam dan lain sebagainya. Dari begitu banyaknya jumlah karyawan dengan jumlah selera yang tak kalah banyaknya, tidak mengherankan jika banyaknya keluhan terhadap menu kantin tidak pernah berkurang.

3) 郷に入っては郷に従え

\section{Gou ni itte wa gou ni shitagae \\ 'Masuk kampung, patuhi kampung' \\ Patuhi aturan yang berlaku di tempat yang baru}

Pada zaman dahulu, ketika belum banyak berdiri kota-kota besar, masyarakat umumnya hanya tinggal di kampungkampung kecil, ketika melakukan perjalanan ke suatu tempat yang cukup jauh dari daerah tempat tinggal, maka kita akan menemukan kampung kecil lainnya. Masyarakat umum yang berperjalanan pada zaman dahulu melakukan perjalanan dengan berjalan kaki karena keterbatasan sarana transportasi. Medan yang dilalui pun tak kalah berat, jalan berbatu, mendaki bukit, melewati sungai dan lain sebagainya. Oleh karena perjalanan tersebut begitu menguras tenaga, begitu menemukan suatu kampung, biasanya orang akan singgah sejenak untuk beristirahat.

Selama berada di kampung baru tersebut, seorang pendatang akan mematuhi aturan yang ada di daerah baru tersebut. Jika orang yang hanya sekadar singgah saja wajib mematuhi aturan, apalagi seorang yang pindah tempat tinggal dari satu kampung ke kampung lainnya. Untuk dapat bersosialisasi dengan baik dengan penduduk setempat, seorang pendatang baru harus menaati aturan yang berlaku di tempatnya berada. Dari pengalaman empiris seperti ini, nenek moyang orang Jepang meyarikannnya ke dalam keikenteki kotowaza 「鄉に入っ て郷に従え」 ini. 
"Karena antara daerah satu dan lainnya berbeda adat dan kebiasaan, maka ketika tinggal di suatu daerah yang baru, patuhi adat istiadat dan kebiasaan yang berlaku di situ", demikian makna dari peribahasa ini. Peribahasa ini mengajarkan cara agar seseorang dapat bersosialisasi dangan baik di lingkungan baru tempat seseorang tinggal. Dengan mematuhi tradisi dan kebiasaan daerah tersebut dan tidak membawa kebiasaan kita sendiri yang bertentangan dengan aturan di lingkungan tersebut, maka seseorang akan diterima oleh masyarakat setempat. Peribahasa ini berhubungan dengan beragamnya karakteristik daerah, dengan kata lain, peribahasa ini termasuk salah satu contoh dari keikenteki kotowaza.

「郷に入って」 yang makna literalnya adalah 'memasuki kampung' memiliki makna 'perihal memasuki sebuah daerah yang baru' - terlepas dari kenyataan apakah daerah tersebut merupakan daerah kecil berupa kampung ataupun kota besar dengan demikian peribahasa ini merupakan peribahasa yang menggunakan majas sinekdok yang mengungkapkan sesuatu yang umum dengan sesuatu yang khusus.

「鄉に従え」 yang makna literalnya adalah 'patuhi kampung', memiliki makna 'patuhi aturan yang berlaku di daerah tersebut'. Sama dengan penjelasan di atas, kata $「$ 鄉 」 memiliki makna 'wilayah/daerah', akan tetapi, yang dipatuhi bukanlah daerahnya, melainkan kebiasaan atau adat istiadat yang menjadi aturan di daerah tersebut. Penggalan peribahasa ini juga menggunakan majas sinekdok karena menggunakan kata 「拫」 yang sifatnya lebih umum untuk menjelaskan'peraturan suatu daerah'yang lebih sifatnya khusus.

Aplikasi peribahasa ini dapat dilihat dalam data kalimat berikut:

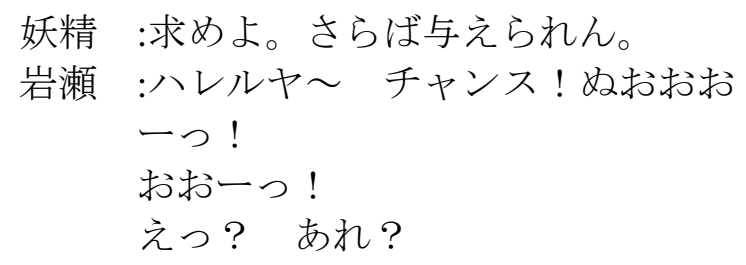

妖精 :すまん。日本人と話してたら，つ

いつい日本語で話しちまったよ。

ここはアメリカだった。

岩瀬 :そういう関係あるんすか?

妖精 :鄉に入っては郷に従え。

Yousei : Motomeyo. Saraba ataeraren.

Iwase : Hareruya chansu! Nooooo..!Ooo..! E? Are?

Yousei : Suman. Nihonjin to hanashitetara, tsuitsui nihongodehanashichimattayo. Koko wa amerika datta.

Iwase :Sou iu kankei arun su ka?

Yousei : Gou ni itte wa gou ni shitagae.

Peri : 'Mintalah. Niscaya akan diberikan. '

Iwase : 'Haleluya chance!Noooo..!Ooo..! Eh? Lho?!'

Peri : 'Maaf. Kalau berbicara dengan orang Jepang,tanpa sadar jadi berbicara menggunakan bahasa Jepang. Ternyata ini Amerika.'

Iwase : Memangnya ada hubungannya?

Peri : 'Gou ni itte wa gou ni shitagae. (ketika masuki kampung, patuhi kampung)'

(http://www.d-addicts.com)

Pada dialog dari kutipan drama di atas, mantra untuk kembali ke masa lalu yang diucapkan tokoh Iwase tidak berhasil bekerja. Menurut peri gereja tersebut, hal ini disebabkan karena mantra 'Haleluya, chance!' tersebut diucapkan dengan logat Jepang oleh Iwase padahal saat itu mereka sedang berada di Hawaii yang merupakan bagian dari wilayah Amerika Serikat. Akhirnya setelah mengucapkannya dengan pengucapan yang benar dalam bahasa Inggris, mantra itu bekerja dan Iwase kembali ke masa lalu.

\section{Simpulan}

Setelah menganalisis data pada bab sebelumnya, penulis mencoba menyimpulkan keseluruhan hasil analisis sebagai berikut:

Jika hubungan antarmakna pada keikenteki kotowaza di analisis melalui kajian linguistik kognitif,kotowaza yang berhubungan dengan berbagai macam karakter daerah dapat dianalis dengan 
Izumi, Volume 5, No 2, 2016

e-ISSN: 2502-3535, p-ISSN: 2338-249X

Tersedia online di http://ejournal.undip.ac.id/index.php/izumi

menggunakan majas sinekdok. Hal ini disebabkan kotowaza yang berhubungan dengan karakteristik daerah menggunakan sebuah kata yang dapat mewakili kata lain yang terdapat dalam makna kiasannya. Sebagai tambahan, dari data yang dikumpulkan, yang termasuk ke dalam kotowaza yang dapat dianalisis menggunakan sinekdok tidak hanya yang berhubungan dengan karakteristik daerah saja melainkan kotowaza lain yang berhubungan dengan angka. Hal ini dikarenakan satu buah angka dapat mewakili makna tertentu seperti banyak atau sedikitnya suatu hal.

\section{KEPUSTAKAAN}

Arimi, Sailal. 2005. Contested Wisdom in Indonesian and Japanese Proverbs.Osaka: 都市文化研究. 6, 76-101.

Kaneko, Takeo. 1982. Nihon no Kotowaza 1. Tokyo: Umitsubame Shobou.

. 1982. Nihon no Kotowaza 2. Tokyo: Umitsubame Shobou.

Kawase, Ikuo. 1996. Nihongo Chukyuи II. Tokyo: Bonjinsha.

Keraf, Gorys. 2010. Diksi dan Gaya Bahasa. Jakarta: PT. Ikrar Mandiriabadi.

Lakoff, G \& Johnson M. 1980. Metafora We Lived By. Chicago: The University of Chicago Press.
Shinmura, Izuru. 1973. Koujien. Tokyo: Iwanami Shouten.

Sutedi, Dedi. 2008. Dasar-dasar Linguistik Bahasa Jepang. Bandung: Humaniora.

2009. Penelitian Pendidikan Bahasa Jepang. Bandung: Humaniora

Yohani, Adisthi Martha. 2008. Peribahasa Jepang Empiris. Program Sarjana Jurusan Sastra Jepang Fakultas Sastra Universitas Padjadjaran (tidak dipublikasikan)

Yulianie, Astie. 2006. Analisis Komparatif Peribahasa Jepang dengan Peribahasa Indonesia yang Berhubungan dengan Mata. Program Sarjana Jurusan Sastra Jepang Fakultas Sastra Universitas Padjadjaran (tidak dipublikasikan) 